肉盛溶接の高付加価値技術の 実際

\section{肉盛溶接としてのレーザ複合加工 技術*}

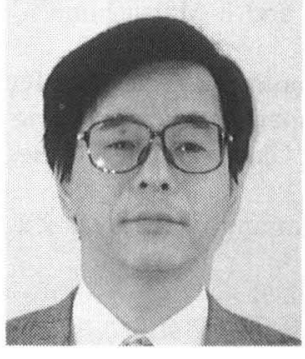

米田 理史

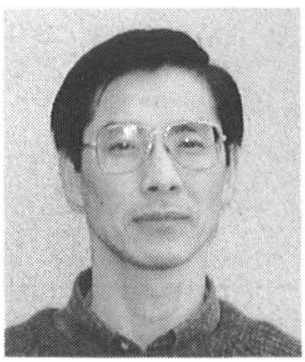

内海 明博

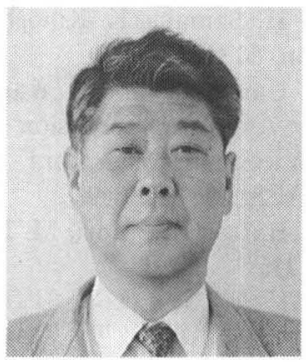

松田純

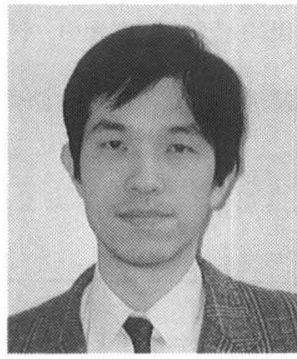

大家 利彦

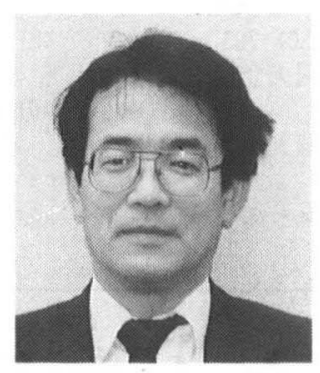

勝村 宗英
1. はじめに

レーザは材料加工ツールとして見た場合，制御性の良 い高エネルギー密度熱源であり, 自由なエネルギー密度 の選択が可能, 非接触加工である, 高速加工ができる, 高融点材料も容易に溶融させることができる,など の利点を有している，また，限定された領域にのみ熱を 与えることができるため加工に伴う材質劣化や歪み が少なく, 生産技術上からも極めて有利な加工手段で ある。

通産省工業技術院においても産業科学技術研究開 発制度により, 平成 9 年度から 5 年計画で高品位フォ トンの発生・利用技術およびフォトンを用いた計測 技術など，フォトンとしてのレーザの特性に着目し た大型プロジェクト「フォトン計測・加工技術」がス

*原稿受付 平成 11 年 4 月 5 日

**正員工業技術院四国工業技術研究所 Member, Shikoku National Industrial Research Institute, AIST, MITI

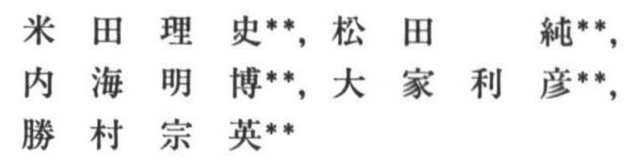

by Masafumi YOMEDA**, Jun MATSUDA**, Akihiro UTSUMI**, Toshihiko OOIE** and Munehidi KATSUMURA**

キーワード : レーザ・アーク複合加工, 高速加工, レーザー摇動, 肉盛溶接, 低希釈率

タートしている.このプロジェクトでは，(1) フォトン 応用加工技術（マクロ加工技術一高信頼性レーザ溶 接一, ミクロ加工技術), (2) フォトン応用計測技術 (in $s i t u$ 状態計測技術, 非破壊組成計測技術), (3) フォ トン発生技術（高出力完全固体化レーザ技術，高集光完 全固体化レーザ技術）の各分野が, NEDO, フォトンセ ンター, 通産省工業技術院研究所, 大学, 企業の産 学官連携で進められ, われわれのグループも川崎重 工業 (株), 大阪大学接合科学研究所, (株) レーザ応用 工学研究所と共同でマクロ加工分野の技術開発に取 ク組んでいる.

われわれは, 現在 $\mathrm{CO}_{2}$ レーザ, YAGレーザなどの 赤外レーザからエキシマレーザなどの紫外レーザを ツールとしたレーザプロセス技術, 特にレーザとレー ザやイオン, アークなど熱源の複合化によるレーザ ハイプリッドプロセス技術の研究開発を進めている. ここでは, レーザハイプリッド化による従来熱源・加工 法の高度化 - 高付加価值化技術として, $\mathrm{CO}_{2}$ レーザと アーク熱源を複合した高速表面処理プロセスを紹介 する. 


\section{2. レーザ複合による TIG アークの安定化}

アークは金属材料の溶接・表面改質などの熱加工分野 では従来から最もよく使われている熱源であり, 表面改 質ではクラッディング（肉盛溶接）などが多くの産業分 野で実用化の域にある.しかし, 一般にアークはエネル ギー密度が低く $\left(\sim 10^{4} \mathrm{~W} / \mathrm{cm}^{2}\right)$, 熱伝導により広い範囲 が加熱されることから材料への投入熱量を大きくする必 要があり，材料の変形や劣化といった熱影響が問題と なっている. 要求される改質層が薄い場合には, アーク の電流值を低くする, あるいは加工速度を大きくするこ とで熱影響を抑制できるが，多くの場合アークが極めて 不安定になり，材料表面でアークの極点が不連続に移動 する結果, 正常な加工が不可能となる、困 1 (a) はこの ような条件下で不安定となった TIG アークの電圧波形, また，（c）は高速度ビデオ（毎秒 400 コマ, シャッター スピード 1/10000 秒) により観察したアークプラズマの 例である.

一方, レーザは極めて高いエネルギー密度 $\left(\sim 10^{7}\right.$ $\left.\mathrm{W} / \mathrm{cm}^{2}\right)$ を発生でき, 溶接や切断など集光させた状態で の高速加工に適しているが, 比較的大きなビームスポッ トを用いる金属材料の表面処理ではレーザの反射率が大 きく，材料の表面状態，種類にもよるが, $\mathrm{CO}_{2} レ$ レ゙ では 90 数\%が反射してしまう場合がある. そのため, レーザのみで十分な熱量を得ようとすると, 高出力の

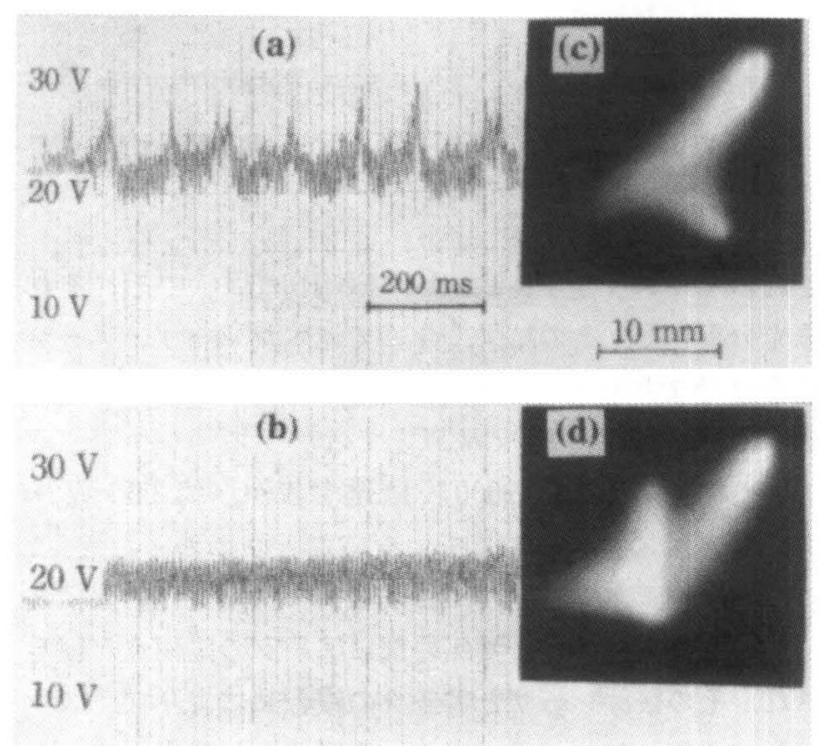

図 1 TIG アーク単独とレーザ・アーク複合熱源におけるアーク 電圧波形とプラズマの挙動

（a）およU゙ (c)：TIGアーク単独

（b）およU゙ (d)：レーザ・アーク複合熱源

レーザ出力 : $2 \mathrm{~kW}$, アーク電流 : $100 \mathrm{~A}$ (DCEN), 基材移 動速度 : $150 \mathrm{~mm} / \mathrm{s}$
レーザ発振器が必要となり, 非常に装置コストが高く なってしまう難点がある.

そこでわれわれは，レーザ照射による局部的な材料加 熱と，その際に材料表面から放出されプラズマ状態と なった高温の蒸気 (レーザプルーム) を積極的に利用し， 高速加工時のアークを安定化，制御する技術の開発を進 めている、レーザ照射部は酸化皮膜が除去されることに 加え高温で, アークの陽極点が固定されやすい.さらら に, レーザ照射によって発生するプラズマは一般に多量 の自由電子を含んだ導電体であることから，アークとの 複合化においては導電経路として効果的に作用し，アー ク単独では不安定となる高速加工域でもアークを安定し た状態に保持できることが予想される，同時に，アーク 熱により材料の温度上昇が生じるため, 材料表面での レーザの吸収率が改善され、レーザエネルギーを高効率 で利用できる効果も期待できる。

これまでにもレーザとアークの複合化による加工プロ

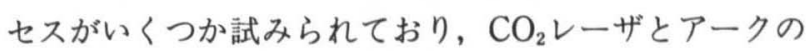
複合化では, 溶接時のアークの安定化 ${ }^{11}$, 厚板の開先内 溶接 ${ }^{2}$ が報告されている。 また，最近ではYAGレーザ とアークとの複合化も検討されている ${ }^{3,4}$. われわれのグ ループでも $\mathrm{CO}_{2}$ レーザと TIG／MIG アークとの複合 レーザ溶接を実施し, 溶け込み深さの増大や要求される 開先精度の楥和に顕著な効果があることを報告してき た5). 今回は従来と少し視点を変え, より高速処理が可 能な表面加工プロセスの開発を目的として, $\mathrm{CO}_{2}$ レーザ によるTIG アークの安定化と制御, および表面処理プ ロセスへの適用を検討した. 図 2 は高速表面加工プロセ スへの適用に対するレーザ・アーク複合化の考え方を概 念的に示したものである.

図 3 はこれらの考え方に基づくレーザ・アーク複合表

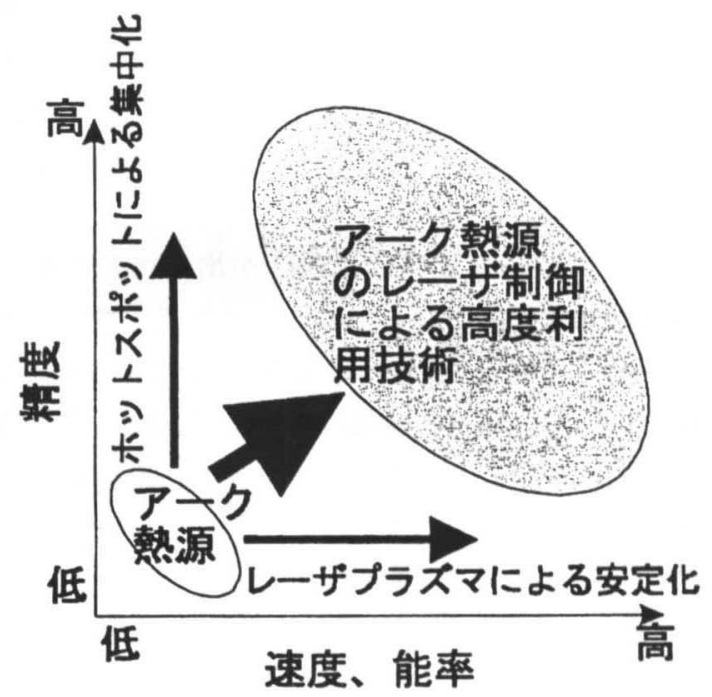

図 2 レーザ・アーク複合化に対する考え方 


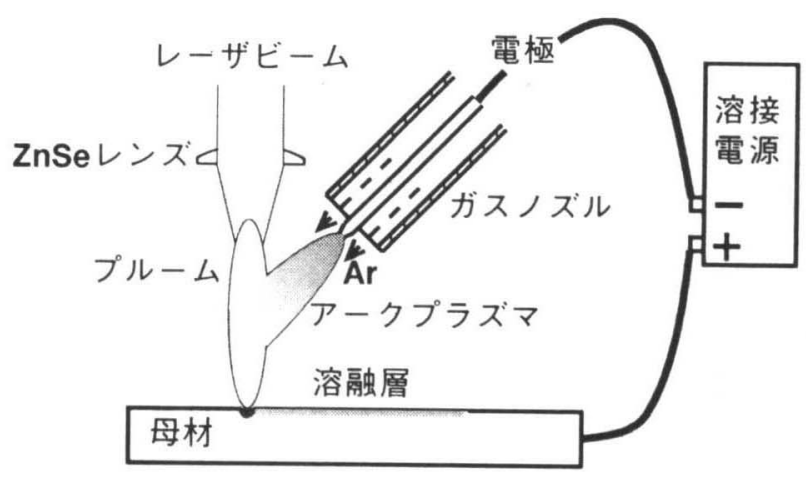

図 3 レーザ・アーク複合表面処理法

表 1 実験条件

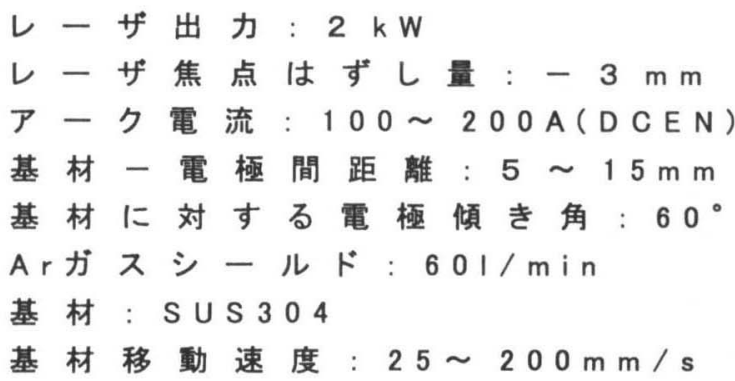

面処理法を，また，表 1 は実験条件を示す。この方法を 適用した場合の高速加工時のアークプラズマの挙動は図 1 (b) および（d）に示す通りであり，単独では不安定な 図 1 (a) の場合のアーク加工条件においてもレーザとの 複合化によりアークが安定化することが確認できた。ま た, レーザ・アーク複合時の電圧波形 (図 1 (b)) からも アークが安定化していることがわかる.

図 4 は基材一電極間距離 $\mathrm{b}$ を変えた場合について, アーク電圧の変動が少なく連続した陽極点の痕跡が得ら れるアークの安定領域を, 基材移動速度およびアーク電 流值で図示したものである（図中の○およU゙×印は $\mathrm{b}=$ $10 \mathrm{~mm}$ の場合についてアークが安定な加工条件および 不安定な加工条件を示す). アークは基材移動速度が増 すほど，またアーク電流が小さいほど不安定になりやす く，さらに，基材一電極間距離 b が増すにしたがって 安定領域が非常に狭くなっている。このようなアークに 対して, 出力 $2 \mathrm{~kW}$ のレーザを併用すると, アークの安 定領域が拡大し，基材一電極間距離 $\mathrm{b}$ に関わらず，基材 移動速度およびアーク電流值がそれぞれ $200 \mathrm{~mm} / \mathrm{s}$ およ び $100 \mathrm{~A} の$ 条件でもアークが安定するようになる。この ように, レーザ・アーク複合熱源は，アーク単独では安 定した加工が不可能な低電流および高速加工領域におい ても安定性が維持される6 .

これらのレーザ複合によるアークの安定化機構を明ら かにするため，鉄基材に対して，レーザ単独照射で形成

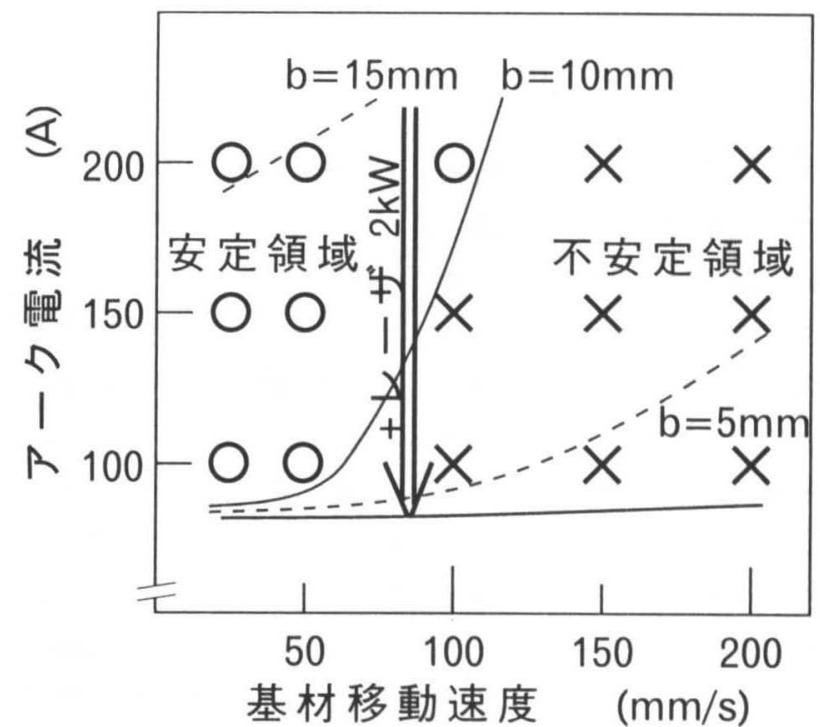

図4アークの安定化領域とレーザ複合の効果

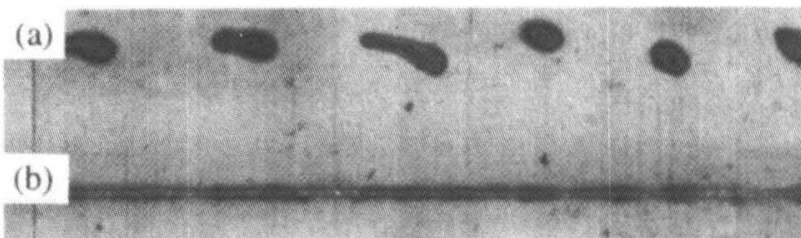

図 5 TIG アーク（a）およU゙レーザ・アーク複合熟源（b）による 表面溶融状況

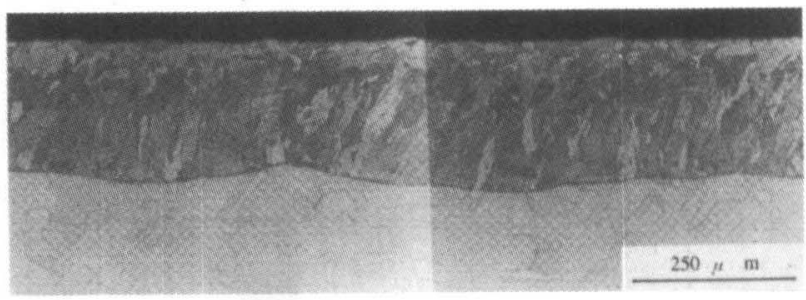

図 6 レーザ・アーク複合熱源による溶融部断面形状

されるプラズマを Fe I および Fe II についてそれぞれ 分光分析した，その結果，今まで述べたレーザ・アーク 複合熱源で用いる焦点位置, Ar ガス流量において, レーザパワーが約 $2.5 \mathrm{~kW}$ 以上ではプラズマが生じ，そ の中心温度は $8000 \sim 9000 \mathrm{~K}$ に達するが，約 $2.5 \mathrm{~kW}$ 未 満ではプラズマが発生していないことがわかった77.こ のことから，本実験範囲におけるアーク安定化の機構と して，まず高温のレーザ照射部にアークの陽極点が固定 され，その後，レーザとアークの複合熱によりプラズマ が形成され，これがアークの伝達経路として作用するよ うになると考えられる。

図 5 は TIG アーク単独およU゙レーザ・TIG アーク複 合熱源により SUS 304 ステンレス鋼板を $150 \mathrm{~mm} / \mathrm{s}$ で 高速溶融処理した例である。アーク単独でこのような高 速加工を行うと，アークが図1 (a) および (c) に示した 


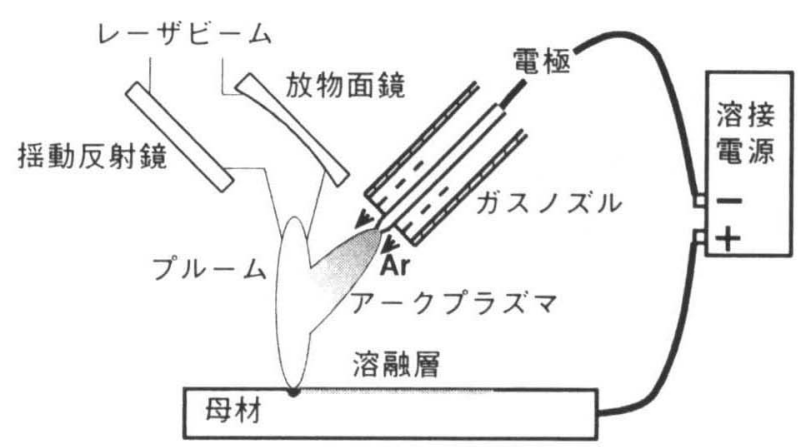

図 7 摇動レーザ・アーク複合熱源

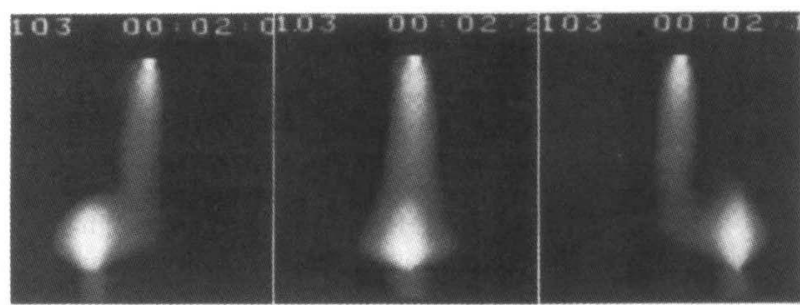

図 8 レーザ摇動によるアークプラズマの挙動

ように不安定になり, 図 5 (a) に示すような飛び石状の 溶融状態になる。これに対し、レーザ・アーク複合熱源 では, 図 5 (b) に示すように安定した溶融状態が得られ ている。また，レーザ・アーク複合熱源による溶融部の 溶融線方向に平行な断面形状 (困 6) では, 表面層のみの 均一な溶け込みが観察される.

\section{3. レーザによる TIG アークの摇動制御と クラッディングへの応用}

前節において，レーザ・アーク複合熱源ではレーザと の複合化によりアークが高速加工域で安定化する現象に ついて説明した。, 次に, この現象を利用し, ビームスキャ ナーにより加工方向に対して直角にレーザビームを摇動し ながらアークの摇動制御を試みた結果について述べる.

困 7 は装置の概念図を示す。なお，レーザビームの摇 動と集光には正弦波で摇動する平面鏡と固定放物面鏡か らなるビームスキャナーを用いた。 その際，レーザ摇動 幅 $8 \mathrm{~mm}$, 基材移動速度 $30 \mathrm{~mm} / \mathrm{s}$ で一定とし, 摇動周 波数を $5 \sim 25 \mathrm{~Hz}$ と変化させた。これ以外は表 1 と同じ 実験条件を用いた。図 8 は摇動周波数が $5 \mathrm{~Hz}$ の場合に ついて，レーザプルームが摇動幅の両端および中央に位 置する時に加工進行方向正面から撮影した高速度ビデオ 画像を示す、レーザプルームの移動に追随してアーク柱 が先端部分で屈曲して振れており，レーザ摇動により TIG アークが摇動制御されていることがわかる。なお, このような現象はレーザの摇動周波数が $25 \mathrm{~Hz}$ の場合 にも認められた ${ }^{8)}$.

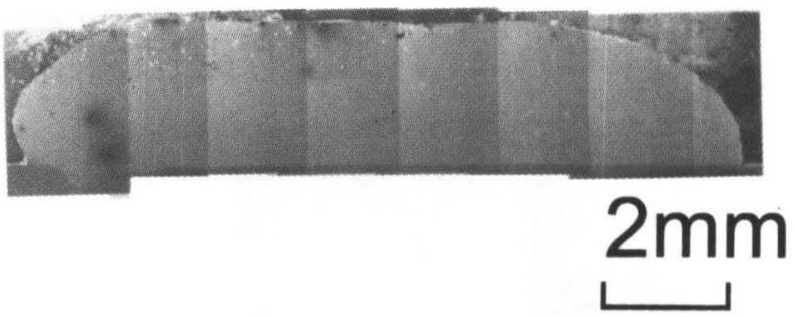

図 9 クラッディング層の断面写真

表 2 クラッディング条件

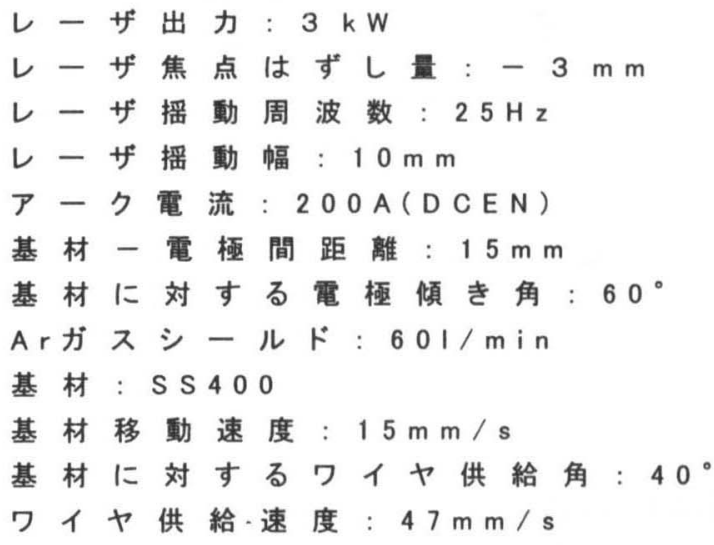

現在，われわれはこのレーザによるアークの摇動制御 技術の応用として, SS 400 軟鋼板上へホワイトメタル (WJ 2) のクラッディングを試みている9). ここでホワイ トメタルは $3.2 \mathrm{~mm} \phi$ のワイヤを用い, TIGトーチの反 対側から供給した.

図 9 は表 2 に示す実験条件で得られたクラッディング 層の断面写真である.レーザビームが短時間ながら停止 する両端部では若干基材が掘れ込んでいる様子が観察さ れるが, 中央部のレーザビームの連続的な摇動域では基 材による希釈はほとんど認められない(この場合の希釈 率は $0.5 \%$ 未満であった)。この部分を EPMA で Fe と $\mathrm{Sn}$ について線分析した結果は図 10 のとおりであり, 界 面で Fe と Snのシャープな遷移が認められ, 組織観察結 果とあわせて基材界面での有害な金属間化合物層の形成 も非常に少ないと考えられる。

このように, TIG アークに $\mathrm{CO}_{2}$ レーザを複合化するこ とでアークの安定化だけでなく，摇動などアークの能動 的な位置制御ができることが確かめられた。この手法は 材料の熱変形や変質, 希釈を抑える高速クラッディング プロセスに対しても有効であると考えられる。

\section{4. お りに}

ここでは, レーザ複合による高速アーク加工の安定化 


\section{Fe White metal}

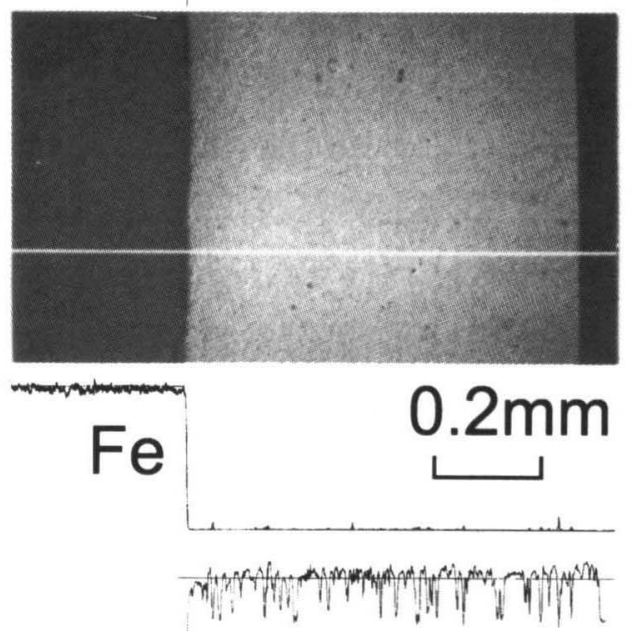

$\mathrm{Sn}$

図 10 基材/クラッディング層界面の組成分析結果

現象およU゙これをアーク制御に利用したレーザ・アーク 複合プロセスを紹介した. 一般に, レーザ加工では, 発 生するプラズマはレーザビームと相互作用し, レーザ ビームを吸収・屈折させるため安定な加工の阻害要因と されているが, われわれはこのプラズマを積極的に利用 し, アーク現象の安定化・制御のみならず, フォトンの 伝達効率 (材料表面でのレーザの吸収率) の飛躍的向上,
Uいてはプロセス面からのフォトンコストの大幅な低減 化に結びつける技術の開発を進めている。 それには，材 料表面ごく近傍での高密度プラズマ層の形成と制御が必 要不可欠な要因となる. 今後, レーザの実用領域拡大に 向けプラズマ制御の重要性はますます高まっていくであ ろう.

\section{考 文 献}

1) W. M. Steen and M. Eboo: Arc Augmented Laser Welding, Metal Construction, 11-7 (1979), 332.

2）阿部, 㯗田, 林, 土谷：レーザ・アーク複合高速溶接にお ける溶接現象の観察, 第 44 回レーザ熱加工研究会論文集, (1998. 7), 15.

3) T. Ishide, Y. Nagura, O. Matsumoto, T. Nagashima, T. Kidera, A. Yokoyama: High Power YAG Laser Welded Sleeving Technology for Steam Generator Tubes in Nuclear Power Plants, Proc. of LAMP'92, (1992), 957.

4) E. Beyer, U. Dilthey, R. Imhoff, C. Maier, J. Neuenhahn, K. Behler: New Aspects in Laser Welding with an Increased Efficiency, Proc. of ICALEO'94, 79 (1994), 183.

5) J. Matsuda, A. Utsumi, M. Katsumura, M. Hamasaki and S. Nagata: TIG or MIG Arc Augmented Laser Welding of Thick Mild Steel Plate, Joining and Materials, 1-1 (1988), 31 .

6) 松田, 内海, 米田, 勝村, 矢納, 荒木 : $\mathrm{CO}_{2}$ レーザによる TIG アークの安定化ーレーザ・アーク併用高速表面処理法の研 究 (第 1 報) - , 本会論文集, 15-3 (1997), 445 .

7) 大家, 内海, 松田, 米田, 勝村, 藤井 : 未発表

8) 内海, 松田, 米田, 勝村, 荒木, 田中： $\mathrm{CO}_{2}$ レーザによるアー クの摇動ーレーザ・アーク併用高速表面処理法の研究一, 本会全国大会講演概要, 60 (1997), 38.

9) 内海, 松田, 米田, 勝村, 多曽田：レーザ・アーク複合熱 源による軸受け合金の肉盛溶接ーレーザ・アーク併用高速 表面処理法の研究一，本会全国大会講演概要，63 (1998), 268.

\section{国際会議のご案内}

会議名：International Brazing \& Soldering Conference

開催期間・会場：2-5 April 2000 • Hyatt Regency Hotel• Albuquerque, New Mexico

連絡先: AWS-C3 Committee

Dr. Ronald W. Smith

President

Materials Resources International

403 Elm Avenue

North Wales, PA 19454

Phone : 215.616.0400

Fax : $\quad 215.616 .0496$

E-Mail : solution@mri-bluebell.com 